\title{
The Effect of a Post-Method-Era-Based-Training Program on Iraqi EFL Secondary School Teachers' Performance
}

\author{
*Shaymaa Sayhood Abbas, **Shaimaa Abdulbaqi Al-Bakri \\ *MA Candidate, English language Department, University of Baghdad, \\ College of Education for Human Sciences-Ibn Rushed -University of Baghdad \\ Bagdad, Iraq \\ ** Professor, English Language Department, University of Baghdad, \\ College of Education for Human Sciences-Ibn Rushed-University of Baghdad \\ Bagdad, Iraq
}

DOI: $10.37648 / \mathrm{ijrssh.v10i03.033}$

Received: $28^{\text {th }}$ June, 2020; Accepted: 31st July, 2020; Published: $18^{\text {th }}$ August,2020

\section{ABSTRACT}

A Training program is an essential requirement in teaching professional development to enrich teachers' skills and academic knowledge, provide modern strategies, and implement global activities. Iraqi EFL secondary school teachers suffer from the lack of training programs based on modern strategies and techniques and from a need of professional development in general. Therefore, this study has been diagnosed the problem in the educational field, and aims at finding out the effect of a designed Post-Method Era-based training program on Iraqi EFL secondary school teachers' performance. It is hypothesized that there is no statistically significant difference between the mean scores of the experimental group and that of the control group in:

1. The overall teaching performance.

2. Teaching performance in pre-instruction dimension.

3. Teaching performance in instruction dimension.

4. Teaching performance in post-instruction dimension.

A population of (980), from which a sample of (60) EFL secondary school teachers is taken randomly from Al-Rusafa $2^{\text {nd }}$ General Directorate of Education, and distributed into (experimental and control) groups. Each of them consists of 30 teachers. The two groups have been equalized in seven variables (age, gender, years of teaching experience, teaching stages, training courses, academic qualifications, and pre-performance test).

An observation checklist and a designed postmethod training program have been used. The findings reveals that the training program has a positive impact on improving teachers' overall performance and particularly in three dimensions pre-instruction, instruction and post instruction. Some conclusions, recommendations, and suggestions have been exposed.

Keywords: Post method era; Training Program; Teachers' Performance. 


\section{INTRODUCTION}

Teachers' performance is an essential factor in the educational process because EFL teachers' quality is very important for the improvement of students' English language performance. The quality of education provided to learners depends on the quality of teachers; the quality of teachers conversely depends on the way in which those teachers receive training through teacher training programs. So Teachers' training needs to be given a great priority in education policies and their plans (Singh and Sharma, 2004, p.65).

Unfortunately, teachers' training is insufficient and frail, and the teaching methods, which are followed, are too old and indicate passive learning without real understanding of the actual contexts.

Regarding the researcher's experiences have perceived that Iraqi EFL teachers at Iraqi secondary schools are suffering from obvious lacks or shortcomings in their classroom performance during classroom observations. Moreover, Iraqi EFL teachers believe that their methodology is the most suitable while it is really out-dated and some of them still stick to traditional approaches.

In addition, Iraqi EFL training programs lack the new techniques, technological equipment, strategies and practices. Moreover the duration of training sessions are not enough. Most of EFL Iraqi training programs are constructed to apply the frequent changes in curriculum content not to improve teachers' quality performance. Besides, the persons who trained teachers are not specialized in ELT field.

As a result, it is important for shedding light on EFL teachers as they are in need for training program that are based on modern strategies and particularly in post-method era in order to raise their quality of performance and to supply them with modern instructions, techniques, strategies in post method era and involve them in the construction of knowledge.

Since there is no prior study in that area, this paper at hand is to fill the gap and aims at finding the effect of a post method era based training program on Iraqi EFL secondary school teachers' performance.

\section{I.}

\section{TEACHER EDUCATION}

Teacher education is an essential component of the quality of educational system. The teacher is considered as the basic stone of the educational process and the most essential element in evolving educational system. The teacher plays many vital roles in educational objectives achievement, educational policies application, the rise of the value of educational facilities, the learning experiences formation, and the learning environment management for the sake of the learners. That is why low students' achievement is often blamed on the teachers' quality (Tabo \& Mottanya, 2012, p.249).

\section{Teacher Quality Characteristics}

The most general characteristics of teachers' quality are:

1. Knowledge of learning and second language acquisition theories, and some psychological aspects related to teaching environment.

2. Knowledge of all traditional and recent methods and approaches of teaching with modern significant techniques.

3. Knowledge of pedagogical practices, skills and how to integrate the four skills of the target language (speaking, listening, reading and writing).

4. Knowledge of language system and the differences between the patterns of the mother tongue language and the target one.

5. Knowledge of various modern technologies and how to integrate them into their instruction.

6. The ability to use language in real life contexts for social and professional purposes and communicate with native speakers.

7. The ability to manage the time, plan good lesson, write instructional materials, and prepare different teaching materials.

8. Having qualifications such as in service professional development.

9. Having good colleague ability to manage a team of teachers.

10. Having a large repertoire of vocabulary and strategies.

11. Having a fluent and correct language of the textbook they teach and of all prior textbooks in the series

12. Having a belief in their ability to motivate students to think independently, critically, and creatively.

13. Having good personal qualities (Sultan, 2014, p.p.1516).

\section{Teacher Professional DeVElopMent}

Professional development (PD) has defined as "a lifelong collaborative learning process that nurtures the growth of persons, groups, and schools during a daily job embedded; learner centered, and emphasized first hand approaches". It has been claimed that PD arises from learning needs and focuses on improving student learning. PD is the development of individuals in their professional roles (Villegas-Reimers, 2003, p.13). According to Villegas-Reimers, the concept of PD is connected to two concepts: career development, which indicates the progress teachers attain during their professional 
career, and staff development which indicates the in-service programs designed at promoting the development of teachers.

Briefly, TPD is "a term used to describe a process of continual intellectual, experiential, and attitudinal growth of teachers". Furthermore, Villeges-Reimers has summarized the characteristics of TPD in the following terms:

- TPD is based on constructivist model instead of on a transmission-oriented model.

- TPD is seen as of long-term process.

- TPD is perceived as a process that occurs within a particular context.

- TPD is confidentially linked with school reform.

- TPD is a collaborative process.

- TPD is based on the notion of reflective practice.

- TPD Stimulates and supports site-based initiative.

- TPD supports teacher initiative as well as school initiatives.

- TPD is grounded in knowledge about teaching.

- TPD offers intellectual, social and emotional engagement with ideas, materials and colleagues.

-TPD demonstrates respect for teachers as professionals and as adult learners.

- TPD provides sufficient time and follow-up support for teachers to master new content and strategies and

to integrate them into their practice.

- TPD is accessible and inclusive.

\section{A. Formal Development Methods}

The word formal refers to the involvement of the authorities and the educational institutes in the teacher development. This part entails two main segments: the preservice and in-service training programs and the teachers' contribution in seminars, conferences, and short-range courses.

a) In-Service Training program (ISTP)

Generally, in- service teacher training means any prearranged program of learning prospects to staff memberships of colleges, schools or any educational organizations for commitments of enlightening the performance of the individual in previously allocated settings. In-service training program has defined as a part of on-going education that supports the trainees to increase insights into their career, extend their knowledge and develop their skills and attitudes.

Concerning in-service training program for EFL teachers, it has been asserted that ISTP must contain four essential components: development of attitudes, skills, knowledge, and application of these in a real situation. Whereas English teacher training programs have to provide them with confidence in themselves, knowledge of students, understanding of their discipline, awareness of the ways in which context affects education, appropriate choices of goals, objectives, materials, strategies and assessments to help as many teachers as possible to learn and grow in skills, content knowledge, and understanding of self and others (Stover, 2006, p.4).

To develop professional teachers, Rahimi (2007, p.3) has indicated that ISTP should develop teachers to be able to:

- Master the content knowledge of the materials they are specialized to teach.

- Have skills and knowledge about teaching/learning in order to teach properly.

- Notice any shortcomings in their teaching and constantly try to improve them.

- Take on a broader pedagogical and moral responsibility.

In-service training program for teachers should be planned to realize the following principles:

- ISTP equips teachers with basic knowledge of various disabilities and their identification.

- ISTP orients teachers with classroom management strategies to meet challenges.

- ISTP develops teachers' skills and usage of aids.

- ISTP gives teachers opportunities to theorize and practice what they theorize.

\section{2) Microteaching}

Microteaching is definitely helps teachers to well understand the progress of teaching and learning. It affords teachers with sufficient opportunities to realize and reflect on their own and others' instructional styles and to attain new teaching practices. The aim of microteaching is to give teachers support, confidence, and feedback by allowing them present a short lesson of what they plan or design to do with their students in front of their friends and colleagues. In addition, microteaching is a primary component of teaching practical part and has a well-defined construction. Microteaching could be defined as a training situation in which a teaching context can be reduced in range or reduced in some systematic means. There are two ways in which teaching may be decreased; the teacher's task can be shortened and made very particular; and the length of the lesson can be reduced. Furthermore, it makes teachers aware of evolving their own skills and strategies. Over microteaching teachers are capable of chasing self-directed, self-observed, and selfinitiated development.

\section{3) Conferences, Seminars, and Workshops}

Conferences, seminars, workshops, and short courses provide teachers with the opportunity to know what is happening in English language teaching globally. They respectively allow teachers to share experiences and ideas with other teachers at work with similar condition of their own. 


\section{4) Action Research}

Action research is a dynamic device that school administrators or teachers could use to solve educational troubles that do not have suitable answers. Action research shows a vital role in the training and qualified development of teachers. Precisely, action research is used with teacher education programs on international and national levels. Action research refers to teacher-initiated class-room exploration which is intended to increase the teacher's awareness of classroom teaching and learning, and to convey changes in classroom practices.

IV.

\section{TEACHERS' PERFORMANCE}

Performance, as Brown (2007, p.35) has defined, is the obviously observable and concrete understanding of competence. It is what someone actually carries out an action or function. Accordingly, teacher's performance refers to the behaviour of a teacher while teaching a class. It is defined in terms of what the teacher does in classroom. Furthermore, teaching performance is actions inside or outside classrooms like lesson planning, lesson delivery, teaching materials manipulation, test preparation and educational technological use and he has added it refers to four definite areas; learner feedback ,learner strategies, authentic material, and alternative assessment.

Teacher performance refers to observable behaviors, both verbal and non-verbal. It means the teacher's teaching behavior which sometimes appears as result or in the form of students' achievement.

Consequently, it has been confirmed that language teachers are at the top of the teachers who need careful preparation because the nature of FL learning and teaching. He has enhanced that SI/FL teachers' preparation of every subject requires a special kind of education based on academic principles, personal attributes and practical experiences that product a remarkable professional development. A teacher can fill a bookshelf with books about education and can study lots of guidelines, principles and standards. The difference between effective teachers and less effective colleagues is not what they read or know but what they really do.

Brown and Lee (2015, p.p.542-544) have stated that there are five factors that make teachers in peak performance:

1- Believe in self

2. Set realistic goals

3- Set priorities.

4- Take calculated risks

5- Reduce and manage stress factors

\section{A. Factors Affecting EFL Teachers' Performance}

There are number of factors that influence teacher performance, they are:

\section{1) Teachers' Attitude}

Attitude can be defined as the habitual ways of reacting to situations. The concept attitude is normally reserved for an opinion which signifies a person's overall disposition towards an object, institution or idea. Attitude may be positive, negative or neutral and also can be general. The teacher should have a positive attitude to teaching. Effective teachers' performance includes optimistic attitude about their students and about being a teacher. So, teachers need to communicate with students about their progresses, and give them praise and feedback.

\section{2) Teacher's Personality}

Teacher's personality is the most critical factor in successful teaching. If teachers have empathy, warmth, sensitivity, and humour they are much more likely to be successful than if they lack these characteristics. In fact, many people argue that without these attributes, an individual is unlike to be a good teacher. Specifically, many studies have shown those traits such as flexibility, a sense of fairness, patience, enthusiasm, creativity, care and interest in the students, all contribute to the effectiveness of teachers especially if they are associated with instructional skills such as provide clear directions ,use hand-on resources.

\section{3) Teachers Mastery of Subject -Matter}

Mastery of subject matter and perception in the interrelationships and professional preparation are based on the basis of general teacher education. General education takes part in people's growth. Specialization offers scholarly knowledge of the subjects to be integrated with professional education driving to novel considerations and skills for professional performance. There are two facts:

1- To make content accessible to students, teachers need flexible understanding of subject matter and appreciate how students learn. So teachers (who understand the difficulties that students typically have, and who know how to diagnose these difficulties and provide certain strategies to overcoming them) can develop the necessary elements of the content knowledge to be taught effectively.

2- To build their understanding of students' subject matter, teachers need to observe students and study the processes of learning; therefore, with this understanding they can develop many strategies for teaching specific topics to the level of students they will teach. 


\section{4) Classroom Management and Planning}

Gebhard (2006, p.80) has defined classroom management (CM) as the way teachers organize what goes on in the classroom. CM refers to set of procedural skills that teachers employ in their attempt to resolve and address discipline problems in the classroom. It consists of practice and procedures that a teacher uses to maintain appropriate environment for teaching and learning.

There are some factors that affect the creation of the class interaction like how much teacher- students talk and what the teachers says, how to keep students on task, how to reduce misbehavior in the class, how the teacher gives instruction and makes language comprehensible to the students. CM will be impacted by different variables such as how classroom space is organized, the way pupils are working (individual, pair, group, etc.), and how to organize time and the way teachers appear and talk.

\section{5) Teaching Styles and Strategies}

Teaching styles defines as a particular pattern of behaviors, beliefs, and needs that a teacher shows in the classroom. Effective teacher's performance displays a set of teaching strategies and styles to maximize students' achievement. Skillful teachers identify that they need to practice a diversity of strategies and methods to encounter the varied learning needs, to capture and maintain student interest and motivation.

\section{6) Reflective Practice}

Reflective Practice has defined as learning from and through experience towards getting different insights of self and practice and it is seen as foundation of professional identity. Reflective teacher has the ability to examine what they do and the decisions that they make critically. This examination is stated as reflection, and the process, as reflective teaching. Reflective teachers always think about what they are doing. They are attentive, analytical, and selfcritical. Good teacher takes the time to consider the influence of their work and the possible needed to change or modify their actions.

\section{B. Teacher Performance and Effective Teaching}

The role of the teacher depends on the function they perform in different activities. A teacher can be controller, assessor, monitor or evidence gather, organizer or task-setter, prompter, resource and tutor, participant, and investigator (Harmer, 2014, p.p116-117). Accordingly, good teacher is not born but is developed. The talent of teaching is formed gradually by, discussion, experimentation, experience and reflection. Being a best teacher needs hard working and enough determination.
A highly competent teacher who can modify and guide students' leaning according to needs and level of intelligence, there is a need to effective and knowledgeable teachers who can be able to use multi methods of teaching and weave the flexible use of pre-existing knowledge into novel inputs through enhancing students' active participation and creativity.

Arends (2007, p.35) has outlined three main functions for teacher's effective work and performance, the leadership which refers to teacher's roles that are anticipated to play in their classroom as planning, and providing motivation. The instructional aspect which refers to processes and methods that teachers employ for example, they provide (day-by-day collaboration) to students. Whereas, the organizational aspect refers to teacher's work in the school containing work with colleagues, and students' parents. Any effective teacher should have professional and personal qualities such as: having knowledge base on teaching and learning, and various skills that required for reflection and problem-solving, besides considering the following:

- Requirements: such as (content knowledge, verbal ability, educational project, teaching experiences, and teacher certifications).

- Personality: Six core indicators have been associated with teacher as a person (i.e.) positive attitude toward the teaching profession, caring, fairness and respect, confident interactions with students, elevation of enthusiasm and motivation for learning, and the real reflective practice.

- Management: Such as non-verbal tools, organization, planning, dealing with student's behavior, observing students during the tsk, and keeping safe environment.

- Organizing: Such as preparing objectives and instructional materials, organizing time and instruction, and organizing the setting according to different tasks.

- Implementing: Such as connection between content and skills, using different questioning and correction strategies, and focusing on student's engagement.

-Monitoring: For example, monitoring students' achievement, responding to students' needs and interests, and checking students' understanding.

\section{V. \\ PoST-Method ERA}

The postmethod era requires the empowerment of classroom practitioner become a strategic thinker and strategic teacher, and competent of theorizing from their actual classrooms. Postmethod indicates a search for an alternative to method rather than alternative method. It identifies the teacher's potential to recognize not only how to teach but also know how to be autonomous with the administrative and academic limitations forced by institution, curricula and textbooks. It encourages the ability of teacher to know how to 
develop a reflective method to their teaching, how to analyze and assess their teaching practice, how to create changes in their classroom, and how to monitor the effects of such changes (kumaravadivelu, 2012, p.10).

Kumaravadivelu (2006a, p.60) has used method to refer to what theorists offer and to what teachers practice and he in (2006b, p.163) has stated that the concept of method carries the following myths:

1. There is a best method out there waiting to be discovered.

2. Methods constitute the organizing standard for language teaching.

3. Method has a historical and universal value.

4. Teachers consume knowledge, and theorists conceive knowledge.

5. Method is non-aligned, and has no ideological enthusiasm.

\section{A. Reasons of Post-Method Emergence}

There has been a shift from method to post-method era because of many reasons:

1. The dissatisfaction with the notion of method has later resulted in the emergence of the postmethod pedagogy.

2. The claim of the death of method and method deficiencies and restrictions.

3. Postmodernism looks to have altered and influenced the awareness of insiders and outsiders of the ELT field. Both native and nonnative specialists seem to have provided confidently in the progress of postmodernism in ELT.

4. Globalization in language teaching has demonstrated itself in the way English is broadly used as the international language or (the shared linguistic code).

5. The claim that 'there is no best method' means that no single method is best for every person, as there are important distinctions in the teaching context that effect what is best. Every teaching context is different and unique.

6. An alteration from (top-down to bottom-up) method is required. The framework of postmethod looks for open-ended and practical terms based on empirical and pedagogical insights that reshape a specific design for classroom teaching and creates situationspecific microstrategies.

7. Teachers' transformation from the old pedagogy to novel one's view and aware of their ideational sides to develop themselves as a teacher and deliver themselves with micro and macrostrategies manipulating on ELT.

8. Learners' passive recipient role and marginalize their roles in the classroom(Sbai, 2019, p.6)

\section{B. Post-Method Pedagogy Definitions}

Kumaravadivelu, the major advocator for this teaching philosophy, (1994, p.537) has defined it as a particular way of teaching that teachers develop according to their experiences, learners' needs and wants, educational policies, and the available resources. It can also refer to teachers' independence to design situation relying on microstrategies or materials and procedures to achieve their desired learning objectives.

Briefly, Postmethod can be well-defined as the manufacture of classroom procedures and ideologies by the teachers themselves based on their preceding and investigational knowledge and/or certain strategies. $\mathrm{He}$ confirms that the notion of method encompasses theorizers creating knowledge-oriented theories of pedagogy while postmethod includes practitioners creating theories of classroom practice (Kumaravadivelu, 1994, p.24).

\section{Post-Method Parameters}

Kumaravadivelu has viewed postmethod pedagogy with three essential pedagogic parameters: particularity, practicality, and possibility. He has recommend macro and micro-strategies in EFL classes.

The parameter of particularity states that any postmethod pedagogy is in a need to be sensitive to a certain group of teachers teaching a specific group of learners chasing a certain group of objectives with a certain established context fixed in a certain sociocultural situation. Teachers must not deliberate local contexts as restraints to be struggled but situations to be satisfied. This is why is called a shift to localization (Kumaravadivelu, 2001, p.538). Later, Kumaravadivelu (2006b, p.171) has referenced that particularity try to facilitate the progression of a context-sensitive, location definite pedagogy that is based on a factual understanding of linguistic, local, cultural, political, and social particularities. A method must be flexible to diverse teaching situations and diverse learners' needs.

Practicality as the second and the vital parameter, relates generally to the relationship between theory and practice. Kumaravadivelu has identified the practice and theory dichotomy as hurtful. O'Hanlon (1993, p.245) has differentiated between professional theory and personal theory. The earlier one is the theory that is generated by experts. The second one is the theory that is developed by teachers (Kumaravadivelu, 2001, p. 540).

Kumaravadivelu has supposed that postmethod teacher must be able to "theorize from their practice and practice what they theorize" (Kumaravadivelu, 2006b, p.173). Kumaravadivelu (2003, p.35) has claimed teachers cannot use that theory otherwise it should be applicable when they put it into practice. He has also mentioned the teacher who tries to derive a theory from his /her practical classroom situation is 
going to deepen visions into difficulties and problems associated with language teaching, that's why certain teachers are unpredicted and they have an unexplainable rationality which is agreed to their teaching goals as it is called teacher's sense of plausibility, the practicality is a thought with the extent to which methods are applicable.

Kumaravadivelu (2006b, p.175) has indicated possibility as the third parameter that seeks to take the sociopolitical awareness that students bring with them to the classroom environment and it can also work as a catalytic agent for identity construction and social transformation. In addition it is related to relations of power and authority. This parameter gives emphasis to the need of developing theories, and social practices over experiences which individuals have involved in their life period, the possibility is the connection between techniques that teacher uses in language instruction and with whom they are teaching (Kumaravadivelu, 2003, p.36).

\section{Post-Method Conditions}

It has claimed that postmethod condition (PMC) could be defined as a state of affairs that forces teachers to reform the relations between the practitioners and the theorizers. Kumaravadivelu has stated that the view of methods led theorizers create theories based on pedagogic knowledge, while the postmethod condition accords the practitioners to theorize from classroom practices (Kumaravadivelu, 1994, p.29).

Three traits are considered to represent PMC. The first trait is that it seeks for an alternative to method rather than being an alternative method. The second trait is teacher autonomy. Teacher has the ability to know how to teach and can handle problems within restrictions. Consolidating teacher autonomy aims at encouraging and enabling teacher to theorize from his/her real practice and practice accurately what he/she has theorized . The third trait is principled pragmatism.

\section{E. Kumaravadivelu's Macrostrategic Framework}

Kumaravadivelu's (2001, 2006a, 2006b) has mentioned his macrostrategic framework. His framework has contained three parameters and ten macrostrategies with several microstrategies in each one.

Macrostrategies are guidelines and general plans, based on which teachers can be able to create their own situationspecific and need-based microstrategies or classroom practice. Macrostrategies can be operationalized by microstrategies which are classroom steps or procedures. Teachers can design or modify their own microstrategies which match their real classroom context (Toofal \& Barjasteh, 2018, p.60).

The three parameters frameworks as well ten macrostrategies epitomize major principled efforts to surpass the limitations of the concept of method. Kumaravadivelu's framework covers of macrostrategies and microstrategies and remarks that these macrostrategies are derived from theoretical, practical and pedagogical awareness which are neutral in theory and method (Tasnimi 2014, p.4).

Toofal and Barjasteh (2018, p.60) have stated the shaping principle is the notion of method as a construct of marginality. It has conditioned the form and function of classroom methodology restraining the practicing teacher from attempting anything totally different. Macrostrategies, grounded on the ideals of particularity, practicality, and possibility, offer the necessary organizing principles that can form the root for an alternative to the concept of method.

Then, Toofal and Barjasteh (2018, p.p.62-64) has summarized the ten macrostrategies, which first proposed by kumaravadivelu as five then he has increase the number to ten, as the following (kumaravadivelu, 2006, p.199)

1. Maximize learning opportunities. 2. Facilitate negotiated interaction.

3. Minimize perceptual mismatches. 4. Activate intuitive heuristic.

5. Foster learning awareness.

6. Contextualized linguistic input.

7. Integrate language skills. $\quad 8$. Promote learner autonomy.

9. Ensure social relevance. 10. Raise cultural consciousness.

\section{F. Post-Method Indicators}

The major indicators of Postmethod Pedagogy are the teacher educator, the teacher, and the learner. From the viewpoint of postmethod, the learner is active and autonomous (Kumaravadivelu, 2006b, p.179). Kumaravadivelu (2001, p.545) has mentioned at first three aspects of the learner autonomy: social, academic, and liberatory; and later, in 2006b, he suggests only two types: academic and liberatory. Kumaravadivelu deliberates the 'academic' view as a narrow vision which pursues to develop in the learner an ability to learn whereas the broad vision 'liberatory' contains an ability to learn to liberate at the similar time.

According to Kumaravadivelu, learning to learn refers to use appropriate strategies to realize ultimate objectives. By using appropriate strategies, learners are can monitor their learning procedure and increase their learning prospective. If academic autonomy permits learners to be operative, liberatory autonomy allows them to be critical thinkers. So, liberatory autonomy verves more aggressively aiding learners replicate themselves and their social realm, shape their learning societies, and manage possibilities and opportunities for investigation. Therefore, learners can be prepared better explanations for problems in learning. Yet, learners can be 
able to achieve a goal with the support of their teachers (Kumaravadivelu, 2006b, p.179).

Kumaravadivelu (2006b, p.182) has stated that the postmethod teacher is considered as an autonomous. This autonomy is fundamental and actually it is the heart of postmethod pedagogy. Moreover, postmethod pedagogy identifies the teachers' prior and current knowledge, and their power to act and teach independently, which stimulates the ability of the teachers to recognize how to improve a reflective approaches to their own teaching, how to analyze and evaluate their own teaching acts, how to initiate changes in their classrooms, and how to monitor or observer the special effects of these changes. All teachers can make action research in their classrooms. The steps of action research are identifying a problematic issue, collecting data about the problem, formulating a strategy to treat with the problem, experience the strategy, and finally witnessing its effects (Richards \& Farrel, 2005, p. 175).

Kumaravadivelu(2006b, p.182) has commented about the duty of the postmethod teacher educator is to construct or create conditions for prospective teacher to obtain required power and autonomy that can permit his/her to reflect on and figure their particular pedagogic experiences, and in definite cases convert such experience.

\section{G. Criticisms to Post-Method}

The identity of both teachers and learners is included under question in postmethod era. Postmethod still stays infancy and needs more research and practice. Akbari (2008, p.645) has stated that postmethod in fact is language teaching beyond the field of practice and possibility. He adds that postmethod is a philosophy not a practice

Kumaravadivelu (2005, p.215-223) has mentioned two sources of obstacles that face postmethod pedagogy; 'ideological barriers and pedagogical barriers'. Pedagogical barriers transact with firmed models of teacher education that depend on a transmission opinion of knowledge and it is the process of conveying a fixed group of preselected, predetermined, and presequenced frame of knowledge starting from the teacher educator to the potential teacher. While the ideological barrier as a barrier which means politics image and what counts is valid knowledge .He has enhanced that over a style of marginalization and self-marginalization, practical knowledge does not find the space and the possibility to be considered as evident, and does not become part of the recognized knowledge of the discourse society. These two barriers hinder prospective teachers to put on their 'sense of plausibility' to their private classrooms.
Accordingly, Kamali(2014, p.826) has stated three problems in postmethod first 'Teachers' over-responsibility', their financial and occupational restraints, and teacher's alibi which means teachers use this idea as an excuse to their lack of knowledge

Moreover, Akbari (2008, p.649) has denotes that Kumaravadivelu (2012) has suggested three kinds of knowledge for an expert language teacher; professional, procedural, and personal. But most teachers who even do not know what postmethod is. He has summarized that in postmethod, we want to transform the teacher into a package of material developer, curriculum designer, examiner, iconography and the like - Jack of all trades - which is called "teacher transformation" and how much it is possible and practical and especially a question without a clear answer yet . The third problem is 'Teacher's one-sleeved straitjacket'.

\section{H. Post-Method Solutions}

Teacher transformation can be more than a minus sign so that changing teachers to a 'jack of all trades', a pack of material developers, syllabus designers, examiners, iconoclasts and etc. But they need some expectations to meet namely, salary, responsibility, trust, and respect (Kamali, 2014, p.827).

Emotion is the heart of all thought, meaning and actions .Making teachers responsible for what they do, giving them trust for the decisions making, and respecting their thoughts and views are the remedy by which postmethod may survive.

Kumaravadivelu (2001, p.538) has consumed clear explanation that every environment, every single learner, or every single teacher wants confident requirements and providing independence to the 'postmethod teacher' to pick the way of teaching is crucial for success. 'Teacher Freedom' is allowing a postmethod teacher feat his/her personal, professional, and procedural knowledge per se and quit macrostrategies which are called teacher's one-sleeved straightjacket.

Later Kumaravadivelu (2012, p.125) proposed a five-stage modular for teacher education which is named as KARDS (knowing, analyzing, recognizing, doing, and seeing) each has contained diverse components. He considers this modular model as the power that teachers do not make an alibi for their deficiency of knowledge because there is no lack of knowledge. Action researches or teachers' theories is essential to increase teachers' qualified, procedural, and personal knowledge and to hear their voices attentively. Pure knowledge is the base for every single pure practice.

VI.

\section{METHODOLOGY}

\section{1) Population and Sampling}

The population of the present study covers Iraqi EFL secondary school teachers at Baghdad Governorate. A sample 
of (60) EFL secondary school teachers is randomly selected from the General Directorate of Education /Al-Rusafa $2^{\text {nd }}$. The sample is distributed randomly into two groups: The experimental and the control. Each of them includes (30) EFL secondary school teachers. The sample has been equalized in age, gender, years of teaching experiences, teaching stages, number of the in-service training courses, academic qualifications, and pre-performance test. See Table 1 and Table 2

Table 1: The Equalization of the Experimental and Control Groups in in Gender, Years of Teaching Experiences, Teaching Stages, Number of the In-Service Training Courses, and Academic Qualifications

\begin{tabular}{|c|c|c|c|c|c|c|}
\hline \multirow[t]{2}{*}{ Variable } & \multirow[t]{2}{*}{ Groups } & \multirow[t]{2}{*}{ No. } & \multicolumn{2}{|l|}{ Chi value } & \multirow[t]{2}{*}{ df } & \multirow[t]{2}{*}{ Sig } \\
\hline & & & computed & critical & & \\
\hline \multirow[t]{2}{*}{ Gender } & Experimental & 30 & \multirow[t]{2}{*}{0.373} & \multirow[t]{2}{*}{3.84} & \multirow[t]{2}{*}{1} & \multirow[t]{2}{*}{ Not } \\
\hline & Control & 30 & & & & \\
\hline \multirow{2}{*}{$\begin{array}{l}\text { Years of } \\
\text { teaching } \\
\text { experiences }\end{array}$} & Experimental & 30 & \multirow[t]{2}{*}{0.439} & \multirow[t]{2}{*}{5.99} & \multirow[t]{2}{*}{2} & \multirow[t]{2}{*}{ Not } \\
\hline & Control & 30 & & & & \\
\hline \multirow{2}{*}{$\begin{array}{ll}\text { stage } & \text { of } \\
\text { teaching } & \end{array}$} & Experimental & 30 & \multirow[t]{2}{*}{0.071} & \multirow[t]{2}{*}{3.84} & \multirow[t]{2}{*}{1} & \multirow[t]{2}{*}{ Not } \\
\hline & Control & 30 & & & & \\
\hline \multirow{2}{*}{$\begin{array}{l}\text { training } \\
\text { courses }\end{array}$} & Experimental & 30 & \multirow[t]{2}{*}{0.089} & \multirow[t]{2}{*}{3.84} & \multirow[t]{2}{*}{1} & \multirow[t]{2}{*}{ Not } \\
\hline & Control & 30 & & & & \\
\hline \multirow{2}{*}{$\begin{array}{l}\text { academic } \\
\text { qualifications }\end{array}$} & Experimental & 30 & \multirow[t]{2}{*}{0.118} & \multirow[t]{2}{*}{3.84} & \multirow[t]{2}{*}{1} & \multirow[t]{2}{*}{ Not } \\
\hline & Control & 30 & & & & \\
\hline
\end{tabular}

Table 2: The Equalization of the Experimental and Control Groups in Age and Pre-Performance Test

\begin{tabular}{|c|c|c|c|c|c|c|c|c|}
\hline \multirow[t]{2}{*}{ Variable } & \multirow[t]{2}{*}{ Groups } & \multirow[t]{2}{*}{ No. } & \multirow[t]{2}{*}{ Mean } & \multirow[t]{2}{*}{ SD } & \multicolumn{2}{|l|}{ t-value } & \multirow[t]{2}{*}{ df } & \multirow[t]{2}{*}{ Sig } \\
\hline & & & & & computed & critical & & \\
\hline \multirow[t]{2}{*}{ Age } & Experimental & 30 & 458.80 & 97.948 & \multirow[t]{2}{*}{0.658} & \multirow[t]{2}{*}{2.00} & \multirow[t]{2}{*}{58} & \multirow[t]{2}{*}{ Not } \\
\hline & Control & 30 & 475.13 & 94.259 & & & & \\
\hline \multirow{2}{*}{$\begin{array}{l}\text { Pre- } \\
\text { performance } \\
\text { test }\end{array}$} & Experimental & 30 & 135.30 & 28.729 & \multirow[t]{2}{*}{0.031} & \multirow[t]{2}{*}{2.00} & \multirow[t]{2}{*}{58} & \multirow[t]{2}{*}{ Not } \\
\hline & Control & 30 & 135.50 & 21.387 & & & & \\
\hline
\end{tabular}

2) The Instrument of the Study

In order to achieve the aim of the study, an observation checklist has been constructed to evaluate teachers' performance before the program and after it. This checklist includes three dimensions (Pre-Instruction, Instruction, and Post-Instruction), each dimension consists of a number of components and each component has a number of items. This checklist is intended to be scored according to Likert-Five points Scale and as the following: Always =5; usually =4; sometimes $=3$; rarely $=2$; and never $=1$.

Ultimately, the total number of the initial form of the observation checklist is (64). The pre-Instruction dimension has (16) items, Instruction dimension has (34) items, and postInstruction dimension has (14) items. After face validity by experts in ELT the final number of items has become (69).
Pearson correlation coefficient has been used to find construct validity. A pilot administration has been administrated to a sample of (20) secondary school teachers who are selected from the General Directorate of Education /Al-Rusafa $2^{\text {nd }}$, to estimate the time required for observing each teacher. Two method are used to estimate the reliability (test-retest method and inter-rater method).

\section{3) Designing the Training Manual Program}

The training program includes a manual and DVD .The manual contains rules and etiquettes; training day structure; and eight chapters. Each chapter comprises of theoretical phase which is known as theoretical issues, a practical phase 
which includes tasks, watching videos phase, microteaching phase, assignment phase and reflection phase. Photocopied worksheets, references and appendices are put at the end of each chapter that should be covered in one week and must be lasted within three hours. While the DVD includes the video films downloaded from YouTube site.

\section{4) The Experimental Application}

The experiment started at 7th of November, 2019 and lasted for eight weeks to be ended on 26th of December, 2019. The training sessions are held on Al -Khanssa Secondary School to make use of the equipment available in the computer hall.

\section{a) The Experimental Group}

The training manual program has been used with the experimental group only. The researcher herself has trained the participants. A package of (brochure of the manual, pens, and DVD) has been given to each participant. In addition a personal laptop, Data Show, Smart Board, Video Films are used as facilitating teaching aids. The procedures are followed in each week:

1. Instructional /teaching aids are prepared initially.

2. Participants are welcomed, organized in alternative named groups, introduced to what they are going to do in the training session, the aim, the content and the procedures.

3. Participants are asked to assign roles for each member (leader, writer, presenter, time keeper, checker, and resource collector.

4. Objectives have been presented, ice -breaking activities have been explained, brainstorming questions have been asked.

5. Theoretical aspects have been presented by power point programme with the support of using data show and smart board while the trainees write down some notes.

6. Think -pair-share, write-pair-share, jigsaw strategies are included.

7. Participants are organized in pair or teams according to the task.

8. The tasks are discussed among participants, and then they summarize their responses and write them on worksheets. One member from each group (the presenter delivers the summary in front of the groups.

9. Video films about the topic are watched and feedback is written on worksheets by the participants.

10. Microteaching is presented by a team member, who is evaluated with peer assessment questionnaire by shedding light on strengths and weakness points.

11. Assignments which are diverse in brands are given as kinds of homework. These assignments can be discussed in groups then sent by Gmail to the researcher. Some beneficial internet sites are delivered to the participants as supplementary factor.

12. Reflection is written down briefly at the end of each week as (questions or responds to a questionnaire).

\section{b) The Control Group}

No treatment is employed with the control group. Thus, this group is selected to control the experiment.

\section{RESULTS}

To achieve the aim of this study, the results of postperformance test are analyzed to find out if there are statistically significant differences between the mean scores of the experimental group who has participated in the training program and the control group. The t-value for two independent samples has been used. See Table 3

Table 3

The Mean, Standard Deviation and Computed t-value for the Experimental and Control Groups

\begin{tabular}{|l|l|l|l|l|l|}
\hline Groups & No. & Mean & SD. & df & $\begin{array}{l}\text { t } \\
\text { computed }\end{array}$ \\
\hline Ex. & 30 & 240.30 & 28.730 & \multirow{2}{*}{58} & 6.850 \\
\hline Con. & 30 & 193.80 & 23.602 & & \\
\hline
\end{tabular}


To determine the size of the training program statistical significant effect on teachers' performance, ETA square formula is used. It yields a value of (0.45) which indicates a great effect. Accordingly, it can be concluded that the Post-Method-Era based training program has a good effect on Iraqi EFL teachers' performance.

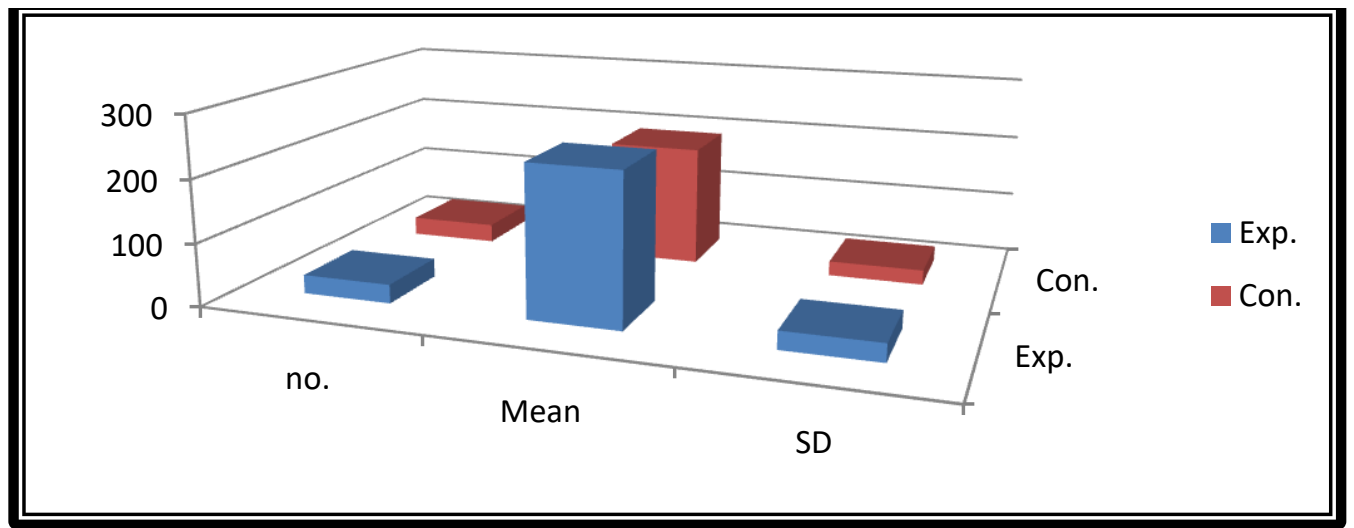

Figure 1 The Mean, Standard Deviation and Computed t-value for the Experimental and Control Groups

As shown in Table 3, Figure 1 the computed t-value is higher than the critical which means there is significant difference in favour for the experimental group.

Figures 2 and 3are illustrated the differences in the three dimensions and the total performance to the two groups (experimental and control) in favour for experimental one.

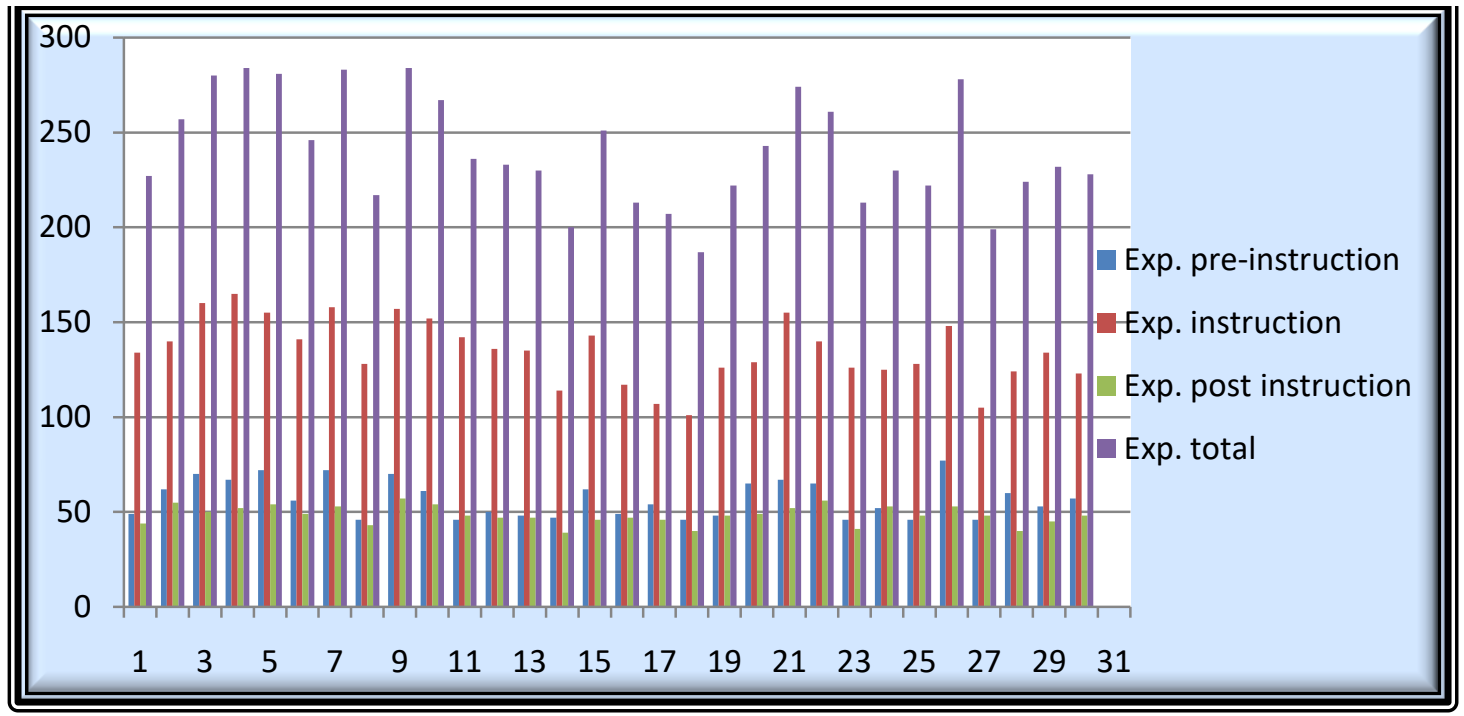

Figure 2: The Differences in the Three Dimensions with the Total Performance of the Experimental Group 


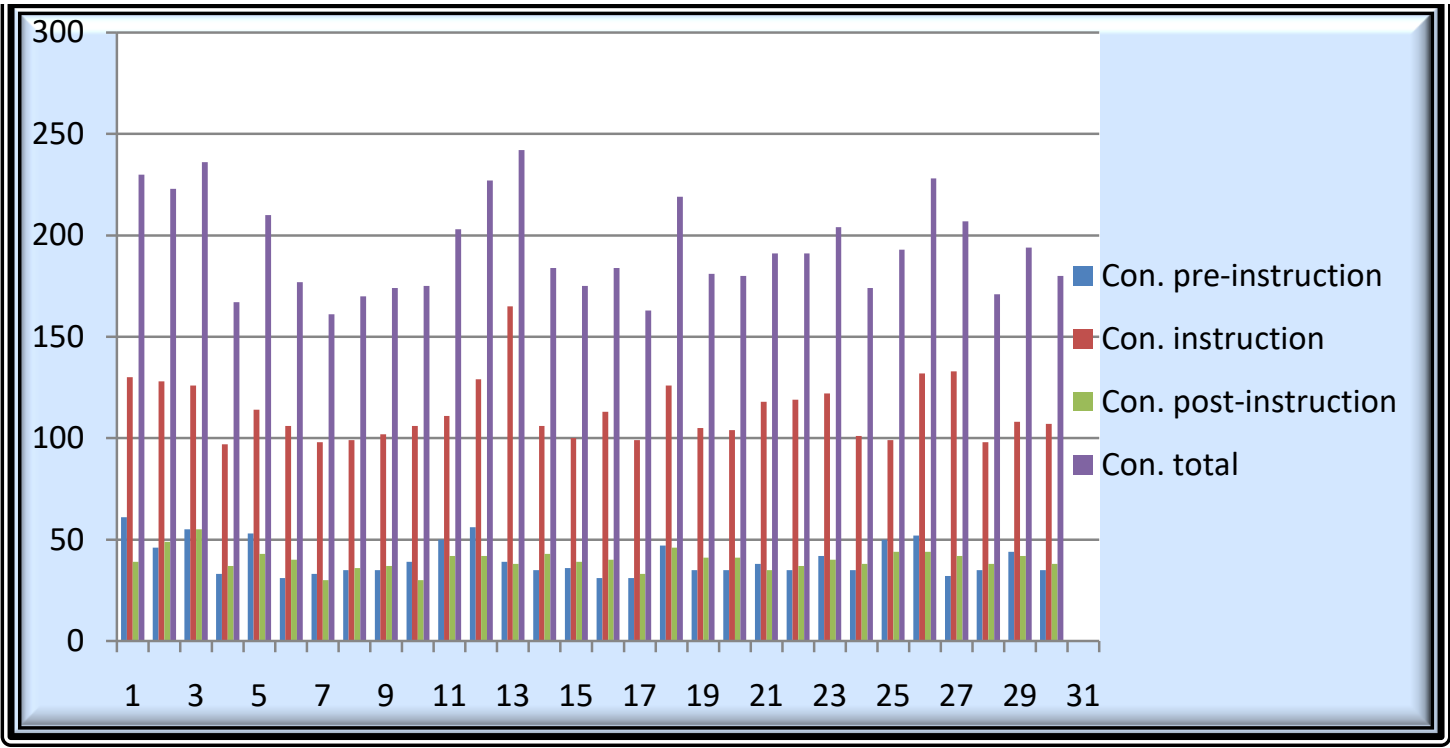

Figure 3: The Differences in the Three Dimensions with the Total Performance of the Control Group

VIII.

\section{CONCLUSIONS}

In the light of the data that are collected before and after the training program, it is concluded that:

1. Iraqi EFL secondary school teachers are really in need of novel or modern in service training programs to improve their teaching performance.

2. The training program based on post method era is found to have a vital effect on developing Iraqi EFL secondary school teachers' performance. It enables teachers to be aware of the local linguistic, political, social and economic situations of the classroom reality and engage in an ongoing cycle of observation, reflection, and action to explore context-sensitive educational knowledge.

3. The training program helps to create autonomous teachers because it is the main goal of postmethod era. It requires them to make decisions, control, apply, evaluate, and reflect on their practice.

4. The training program enhances teachers' knowledge by immersing teachers with a lot of new concepts such as context, identity, affective and cognitive variables, critical practice, teacher autonomy, reflection, action research, teacher philosophy, doublespeak, intuitive heuristics, consciousnessraising, noticing the gap, contextualization of linguistic input, critical cultural consciousness besides various types of new information.

5. The use of group-work, pair-work, and team-work has an effective role on teachers' future performance by using a proper way of grouping their students.
6. Some Iraqi EFL secondary teachers apply modern techniques, but they do not know the concepts' name or do not apply them in appropriate way.

7. The General Directorate of Education and the General Directorate of Preparation and Training Teachers ignore the importance of training teachers on modern topics, especially on Post-Method Era, by experts in ELT. Meanwhile, the application of the present study proves that training in general is very important and essential for teachers because it gives them time to refresh their minds with a lot of information they may know but do not use, new activities that give them a lot of enjoyments, a spirit of competition because they go back as students and begin to discuss and exchange conversations with their colleagues. So, they return to their classes with energy, activity, spirit of challenge to change and improve the real situation for better one.

8. The competent teachers are incredibly eager to learn about Post-Method Era as well as less competent and this program encourages and motivates teachers to use technological materials such as smart board, data show, charts, drawings, DVD, Mp3, microphone to support them in present a good lesson.

\section{RECOMMENDATIONS}

The following recommendations are proposed:

In the light of the results and conclusions, the following recommendations are put forward:

1.Teacher training program duration have to be not less than one month to give teachers the appropriate amount of time to 
cover the important and modern teaching strategies and techniques which offer teacher professional development.

2. The Ministry of Education are invited to establish training programs based on Post-Method Era to the same population in other education directorates because a lot of teachers do not know about this era and even their supervisors. They should also train trainers on this program to develop teacher's training courses and programs in the light of teachers' actual training needs using different means like conducting action research. Additionally, to get rid of the digital literacy, teachers have to be trained on how to use electronic education such as Zoom cloud meetings, Google classroom, free conference call, and meet programme or I-spring programme.

3. EFL Syllabus designers in the Ministry of Education are invited to take in considerations the postmethod macrostrategies and give teachers opportunities to be autonomous when designing textbooks.

4. The General Directorates of Education have to prepare appropriate training rooms which are equipped with various modern technical teaching aids, and have to emphasize on regular training or workshops that give teachers opportunities to discuss with their colleagues and supervisors; support training programs with up-to date strategies and teaching techniques; and focus on technological materials in their training courses such as smart board, data show, and YouTube videos.
5. EFL supervisors are recommended to use the observation checklist of this study to evaluate teachers' performance at least twice in the year, encourage teachers to be reflective and to use reflective approaches such as recording their lessons, writing self -report, using peer observation, establishing professional journal or magazine, and motivate teachers to conduct their own research to find out the problems that face them in their real classrooms.

6. College of Education/English Language Department has been recommended to apply a training program based on Post Method Era to students teachers as a kind of pre-service training. They can add Post Method Era to their syllabuses in third grade or fourth grade. They also need to cooperate with principals in the Ministry of Education to hold training courses, conferences, and workshops to overcome all the complications that teachers and students teachers can face during their future career.

7. EFL teachers should care for self-professional development and have to keep in touch with modern strategies, techniques, warm up activities, modern instructional teaching aids by reading recent editions of books or researches or joining groups on Facebook to make their teaching more effective. There are lots of Facebook pages or groups that support English Language Teacher such as Sowjanya's TLM creative Crafts or Teach it DIY. They need to join EFL training programs, seminars or symposiums, workshops, and conferences to get benefits from exchanging their perspectives and experiences on the strategies of teaching andlearning.

\section{REFERENCES}

Akbari, R. (2008). Postmethod discourse and practice. TESOL QUARTERLY 42(4), 641-652. https://onlinelibrary.wiley .com/doi/abs/10.1002/j. 1545-7249.2008.tb00152.x

Arends, I. R. (2007). Learning to Teach. McGraw-Hill. https://hasanahummi.files.wordpress.com/2017/04/connect-learn-succeed

Brown, D.H. (2007). Principles of language learning and teaching. (5 ${ }^{\text {th }}$ ed.). Pearson Education.

Brown, D. H. \& Lee, H. (2015).Teaching by principles. An interactive approach to language pedagogy. (4 ${ }^{\text {th }}$ ed.).Pearson Education, Inc.

Harmer, J. (2014). The Practice of English Language Teaching. ( $5^{\text {th }}$ ed.). Pearson Education.

Kamali, J. (2014). Post method survival. Procedia Social and Behavioural Sciences, 98, 824-829. DOI: 10.1016/j.sbspro. $\underline{2014.03 .487}$

Kumaravadivelu, B. (1994). The postmethod condition: (E)merging strategies for second /foreign language teaching. TESOL Quarterly, 28(1), 27-48. 
Kumaravadivelu, B. (2001). Toward a postmethod pedagogy. TESOL Quarterly, 35, 537-560. http://dx.doi.org/ 10.2307/3588427

Kumaravadivelu, B. (2003). Beyond methods: Macrostrategies for language teaching. Yale University Press.

Kumaravadivelu, B. (2005). In defence of post-method. ILI Language Teaching Journal, 1(1), 15-19.

Kumaravadivelu, B. (2006a). TESOL Methods: Changing tracks, challenging trends. TESOL Quarterly, 40 (1), 59-80. http://citeseerx.ist.psu.edu /view doc/download? doi=10.1.1.542.6139\&rep=rep1\&type=pdf

Kumaravadivelu, B. (2006b). Understanding language teaching: From method to postmethod. Lawrence Erlbaum.

Kumaravadivelu, B. (2012). Language teacher education for a global society: A modular model for knowing, analyzing, recognizing, doing, and seeing. Routledge. https://core.ac.uk/reader/194897002

O'Hanlon, C. (1993). The importance of an articulated personal theory of professional development, in J. Elliott (Ed.). Reconstructing Teacher Education: Teacher Development. London: The Falmer Press, pp. 243-255(1993).

Rahimi, M. (2007). What do we want teaching-materials for an EFL teacher training programs? Asian EFL Journal. https://www.asian-efl-journal.com/pta_Oct_08.pdf

Sbai, M. A. (2019, April). Post-method pedagogy in Moroccan EFL classrooms: public high schools in Meknes city as a case study. [paper presentation] English Language Needs Analysis conference, Meknes, Morocco. https://www.researchgate.net/ publication $/ 332277372$

Singh, Y. K., \& Sharma, A. (2004). Micro-Teaching. APH Publishing Corporation.

Sultan, M. H. (2014). Evaluating EFL Teachers' Performance in Accredited and Non-accredited Preparatory Schools in the Light of Contemporary Standards [published master thesis]. Mansoura University, Faculty of Education Curricula \& Instruction Dept.

Stover, L. T. (2006). Guidelines for the preparation of teachers of English language arts .National Council of Teachers of English. $\left(6^{\text {th }}\right.$ ed.). http://ncte.org/app/uploads/2018/07/Guidelines_for_Teacher_Prep_2006.pdf

Tasnimi, M. (2014). The role of teacher in the postmethod era. An International Journal of Multi-Disciplinary Research.1(3),1-8.

Tabot, B., \& Mottanya, C. (2012).Contextual characteristics of teaching practice schools on STs' performance. Moi University.

Toofal, Z. Z., \& Barjasteh, H. (2018). Postmethod era in education . Islamic Azad University. ISRES Publishing. https://www.isres.org/books/ chapters/rhes2018-6 31-12-2018.pdf

Villegas-Reimers, E. (2003). Teacher professional development [an international review of the literature]. UNESCO: International Institute for Educational Planning. 